\title{
Ocular Surgery in Ophthalmic Zoster
}

\author{
R. J. MARSH and M. COOPER \\ London
}

\begin{abstract}
Summary
Surgical outcome after ophthalmic zoster was analysed with respect to cataract, glaucoma, corneal ulceration and scarring. We used data from the Zoster Clinic and Hospital Activity Analysis (HAA) at Moorfields Eye Hospital and a lipid keratopathy database at the Western Ophthalmic Hospital.

Conventional surgery for cataract, glaucoma and corneal scarring gave good results which were probably no different from experience with routine cases, although there was a tendency for prolonged post-operative inflammation. Lateral and central tarsorrhaphy for neuroparalytic ulceration almost invariably led to rapid healing.
\end{abstract}

Many ophthalmologists are apprehensive about operating on eyes that have been affected by herpes zoster ophthalmicus because they fear peroperative and postoperative complications associated with inflammation. Therefore elective intraocular surgery tends to be avoided. A survey of the literature is disappointing with only small numbers of cases reported. ${ }^{1,2,7}$ The commonest complications requiring surgery are neuroparalytic ulcers, cataracts, glaucoma and corneal scars. ${ }^{1,2}$ Ulceration occurs in $6-8 \%$ of patients with neuroparalytic keratitis and in less than $3 \%$ with the chronic exposure type of keratitis. ${ }^{3,4}$ Cataracts may precede, be aggravated or precipitated by zoster and often complicate chronic iritis with iris atrophy. They can also be caused by long term use of potent topical steroids which may be necessary in the indolent ocular inflammations with zoster: They may be posterior subcapsular or nuclear. ${ }^{5}$ Glaucoma, too, may precede zoster but usually complicates disciform and mucous plaque keratitis. Occasionally the picture is complicated by topical steroid-induced glaucoma ${ }^{6}$ Corneal scarring follows a small number of nummular, disciform and sclerokeratitis, sometimes forming a vascularised lipid keratopathy ${ }^{6}$ but otherwise complicates neuroparalytic and exposure keratitis. Whilst ulceration or glaucoma may need surgery whatever the underlying causes, cataract or corneal grafts tend to be avoided because the contralateral eye is usually normal. Our data intended to help in evaluating the risks associated with such surgery.

In view of the large number of cases of ophthalmic zoster seen at Moorfields Eye Hospital we felt we had a unique opportunity to see if these fears for surgery were justified.

\section{Patients and Methods}

Case-finding was done by reference to the Zoster Clinic, the Hospital Activity Analysis (HAA) at Moorfields, and the lipid keratopathy database at the Western Ophthalmic Hospital. The Zoster Clinic was started in 1968 by Professor Barrie Jones. From 1973 accurate prospective records were kept and in 1985 these and all new patients details were 
added to a computer data base. Up to now 1700 patients have been seen and 1243 records of those with regular follow-up computerised. The majority of primary and secondary referrals to Moorfields Eye Hospital pass through the Zoster Clinic. The HAA, the main in-patient diagnostic data base for Moorfields, was searched over the same period as the Zoster Clinic for cataract surgery, glaucoma surgery and corneal grafting associated with zoster. The data base of 85 patients with lipid keratopathy referred to the Western Ophthalmic Hospital, London for corneal angiography was searched for those with zoster who had been subsequently grafted. The records were extracted and scrutinised with relevant cases included in the series.

Tarsorrhaphies were temporal third as first choice and classified as carried out either within the first three months or subsequently. They were tabulated as follows:- the type of corneal problem, early or late tarsorrhaphy, central or temporal, the number of these carried out or expanded on an individual case, time for epithelial healing, late complications and if reopening was successful.

Cataract cases were tabulated according to age, date of zoster onset, acute complications, whether they had prezoster cataract, type of operation, pre- and postoperative visual acuity, length of postoperative follow up and finally a note on late complications.

Glaucoma cases were similarly tabulated with the addition of whether there was prezoster glaucoma, the pre- and postoperative intraocular pressures, and whether the patient was on or off glaucoma medication postoperatively.

Grafts were tabulated on a similar basis with the addition of whether the cornea was vascularised preoperatively and if there had been argon laser therapy to the feeder vessels.

It was not possible to carry out reliable statistical comparisons. We had a relatively small sample of cases and groups for comparison were very heterogeneous and virtually impossible to match. A search of the literature, too, yielded no satisfactory comparable surgical results in otherwise healthy eyes.

\section{Results}

Tarsorrhaphy: 45 patients were recorded on the computer of which 40 had adequate follow up. Eleven of these were carried out early and 29 late. Neuroparalytic ulcers were responsible for ten in the former and twenty in the latter, the rest were due to a combination of exposure keratitis, partial loss of sensation and chronic oedema. Thirteen patients had two or more procedures due to disintegration, premature opening and insufficiency of the tarsorrhaphy (six of these were temporals extended centrally). Accurate data on epithelial healing time was available in 29 cases of which 13 recovered within a week, ten within one to two weeks and six were over two weeks. Reopening was successful in five of 12 cases.

Cataracts: (Table I) Eighteen patients had cataract extractions of which eleven were extracapsular with posterior chamber intraocular lenses (one was a triple procedure), two were pure extracapsular and five intracapsular procedures. Accurate follow-up of more than one year was available in 17 cases. Thirteen patients achieved $6 / 12$ or better corrected visual acuity, four did not because of pure corneal scarring in two, macular degeneration in one and a combination of both in one. Topical corticosteroids had to be increased and continued for a prolonged period in three cases because of relapsing iritis.

Glaucoma: (Table II) Twelve patients had glaucoma surgery of which nine were trabeculectomies (one was a triple procedure), one was argon laser trabeculoplasty, and two were peripheral iridectomies for complicating closed angle glaucoma (one occurring after a delay of a year). Accurate follow up for at least a year was achieved in eleven cases. The glaucoma was controlled in nine patients without medical therapy and the remaining two required hypotensive drops. The vision deteriorated in seven patients because of cataract in six and a vitreous haemorrhage in one. The latter occurred unaccountably two weeks postoperatively and had not cleared one year later.

Corneal Grafts: (Table III) Nine patients had corneal grafts of which six were pure perforating keratoplasties, two combined with extracapsular extraction with intraocular lens 
Table I Cataract extractions

\begin{tabular}{|c|c|c|c|c|c|c|}
\hline $\begin{array}{l}\text { Patient } \\
\text { initials }\end{array}$ & Age & $\begin{array}{c}\text { Zoster } \\
\text { complications }\end{array}$ & $\begin{array}{l}\text { Pre Zoster } \\
\text { cataract? }\end{array}$ & $\begin{array}{c}\text { Type of cataract } \\
\text { operation }\end{array}$ & $\begin{array}{c}\text { Post op } \\
\text { va }\end{array}$ & $\begin{array}{c}\text { Post op } \\
\text { problems }\end{array}$ \\
\hline LW & 35 & disciform \& iritis & - & $\mathrm{E} / \mathrm{C}+1 \mathrm{OL}$ & $6 / 9$ & iritis \\
\hline IW & 83 & disciform \& iritis & - & $\mathrm{E} / \mathrm{C}+1 \mathrm{OL}$ & $6 / 36$ & $\begin{array}{l}\text { macular } \\
\text { degeneration }\end{array}$ \\
\hline RJ & 41 & iritis & - & $\mathrm{E} / \mathrm{C}+1 \mathrm{OL}$ & $6 / 9$ & iris atrophy \\
\hline RW & 75 & iritis & - & $\mathrm{E} / \mathrm{C}+1 \mathrm{OL}$ & $6 / 9$ & \\
\hline FM & 63 & iritis & - & $\mathrm{E} / \mathrm{C}+1 \mathrm{OL}$ & $6 / 12$ & \\
\hline $\mathrm{JC}$ & 54 & disciform \& iritis & - & $\mathrm{E} / \mathrm{C}+1 \mathrm{OL}$ & $6 / 9$ & iritis \\
\hline $\mathrm{CC}$ & 93 & iritis & Yes & $\mathrm{E} / \mathrm{C}+1 \mathrm{OL}$ & $6 / 12$ & \\
\hline $\mathrm{KL}$ & 56 & disciform \& iritis & - & $\mathrm{E} / \mathrm{C}+1 \mathrm{OL}$ & $6 / 12$ & lipid keratopathy \\
\hline IA & 66 & iritis & Yes & $\mathrm{E} / \mathrm{C}+1 \mathrm{OL}$ & $6 / 6$ & \\
\hline GM & 73 & iritis & Yes & $\mathrm{E} / \mathrm{C}+1 \mathrm{OL}$ & $6 / 9$ & \\
\hline $\mathrm{CW}$ & 45 & disciform \& iritis MPK & - & Triple Proc & $6 / 6$ & \\
\hline AA & 64 & neuroparalytic keratitis & Yes & $\mathrm{E} / \mathrm{C}$ & $\mathrm{HM}$ & descemetocele \\
\hline RL & 50 & disciform \& iritis MPK & - & $\mathrm{E} / \mathrm{C}$ & $6 / 6$ & iritis \\
\hline HW & 85 & disciform \& iritis & - & $\mathrm{I} / \mathrm{C}$ & $6 / 18$ & $\begin{array}{l}\text { macular } \\
\text { degeneration }\end{array}$ \\
\hline TS & 71 & sclerokeratitis and iritis & - & $\mathrm{I} / \mathrm{C}$ & $6 / 24$ & corneal scar \\
\hline LC & 64 & iritis & - & $\mathrm{I} / \mathrm{C}$ & $6 / 9$ & corneal scar \\
\hline $\mathrm{AB}$ & 65 & $\begin{array}{l}\text { neuroparalytic keratitis } \\
\text { \& iritis }\end{array}$ & & $\mathrm{I} / \mathrm{C}$ & $6 / 9$ & \\
\hline
\end{tabular}

(equal distribution of sexes)

$\mathrm{MPK}=$ Mucous plaque keratitis

$\mathrm{E} / \mathrm{C}=$ Extracapsular cataract extraction

$\mathrm{I} / \mathrm{C}=$ Intracapsular cataract extraction

implantation and one was lamellar. Vessels were closed preoperatively with the laser in three cases. Accurate follow up for at least a year was achieved in eight patients. Corrected visual acuities of $6 / 12$ or better were achieved in seven patients. The one neuroparalytic ulcer had perforated and was grafted with a generous lateral third tarsorrhaphy performed at the same time. This functioned well for four years but then decompensated probably due to the poor quality of the donor corneal endothelium.

\section{Discussion}

Bearing in mind the severity of the associated ocular disease these results were better than anticipated. Tarsorrhaphy led to rapid corneal epithelial healing, the visual results in the cataract and graft patients were excellent and the postoperative pressure control in the glaucoma cases was also good. Thus, apart from the need to increase topical steroids in a minority of patients for relapsing keratitis and iritis the surgical procedures were straightforward.

The rapid corneal epithelial healing achieved by tarsorrhaphy facilitated safer topical steroid application for underlying iritis and keratitis and the patient needed to be seen less often. On reflection it may be better to intervene early because there seemed to be less subsequent scarring and fewer outpatient visits. However, our rate of tarsorrhaphies has been declining in the last two years and we felt that this was due to a more aggressive policy of using Blenderm tape to temporarily close the eye and to the use of Botulinu toxin A injection into the levator palpebrae to achieve a temporary complete ptosis. ${ }^{8}$

There were fewer cataract operations than we anticipated and we had the impression that this was due to reticence to operate rather than a lower incidence of cataract in zoster patients. Perhaps, too, many were unilateral cataracts and it appeared unnecessary to operate on most of them. Nevertheless intraocular implantation seemed particularly successful, in our highly selected group.

Along with some relapsing keratitis and iritis, cataract complicated a third of our trabeculectomies. There was a definite reluctance to remove these which we felt was not 
Table II Glaucoma surgery

\begin{tabular}{|c|c|c|c|c|c|c|c|}
\hline $\begin{array}{l}\text { Patient } \\
\text { initials }\end{array}$ & Age & Zoster complications & $\begin{array}{l}\text { Pre zoster } \\
\text { glaucoma }\end{array}$ & $\begin{array}{l}\text { Type of } \\
\text { operation }\end{array}$ & $\begin{array}{c}\text { Post op } \\
\text { V/A } \\
\text { worse } 6 / 18\end{array}$ & $\begin{array}{c}\text { On } \\
\text { glaucoma } \\
\text { treatment? }\end{array}$ & $\begin{array}{l}\text { Post op } \\
\text { problems }\end{array}$ \\
\hline RL & 50 & Disciform \& MPK & - & Trabeculectomy & Yes & - & Cataract \\
\hline $\mathrm{JC}$ & 68 & Disciform \& MPK & Yes & Trabeculectomy & Yes & - & Cataract \\
\hline GK & 57 & Disciform \& MPK & - & Trabeculectomy & - & - & - \\
\hline MS & 63 & Iritis & - & Trabeculectomy & Yes & - & Cataract \\
\hline FG & 52 & Disciform & Yes & Trabeculectomy & - & - & - \\
\hline CG & 54 & Iritis & Yes & Trabeculectomy & Yes & - & Cataract \\
\hline HB & 77 & Disciform & - & Trabeculectomy & Yes & - & $\begin{array}{l}\text { Vitreous } \\
\text { Haemorrhage }\end{array}$ \\
\hline ML & 62 & Delayed closed angle & Yes & Laser PIs & Yes & Yes & Cataract \\
\hline $\mathrm{AF}$ & 73 & $\begin{array}{l}\text { Iritis and acute closed } \\
\text { angle }\end{array}$ & - & PIs & - & - & - \\
\hline $\mathrm{AM}$ & 50 & Disciform and scleritis & - & ALT & - & - & - \\
\hline \multicolumn{8}{|c|}{$\begin{array}{l}\mathrm{PI}=\text { peripheral iridectomy } \\
\text { ALT = argon laser trabeculoplasty } \\
\text { MPK = mucous plaque keratitis }\end{array}$} \\
\hline \multicolumn{8}{|l|}{ Table III } \\
\hline $\begin{array}{l}\text { Patient } \\
\text { initials }\end{array}$ & Age & Zoster complications & $\begin{array}{l}\text { Pre op } \\
\text { laser }\end{array}$ & Type of graft & $\begin{array}{l}\text { Post op } \\
\text { V/A }\end{array}$ & $\begin{array}{l}\text { Follow up } \\
\text { in years }\end{array}$ & $\begin{array}{c}\text { Post op } \\
\text { problems }\end{array}$ \\
\hline ID & 56 & $\begin{array}{l}\text { Disciform and lipid } \\
\text { keratopathy }\end{array}$ & - & Penetrating & $6 / 9$ & 9 & Rejected \\
\hline VB & 60 & $\begin{array}{l}\text { Disciform and lipid } \\
\text { keratopathy }\end{array}$ & - & Penetrating & $6 / 9$ & 9 & \\
\hline DJ & 24 & $\begin{array}{l}\text { Disciform and lipid } \\
\text { keratopathy }\end{array}$ & - & Penetrating & $6 / 9$ & 3 & \\
\hline IE & 69 & $\begin{array}{l}\text { Disciform and lipid } \\
\text { keratopathy }\end{array}$ & Yes & Penetrating & $6 / 12$ & 5 & $\begin{array}{l}\text { Cataract } \\
\text { extracted }\end{array}$ \\
\hline JC & 70 & $\begin{array}{l}\text { Sclerokeratitis \& } \\
\text { lipid keratopathy }\end{array}$ & Yes & $\begin{array}{l}\text { Penetrating } \\
\text { E/C \& 10L }\end{array}$ & $6 / 9$ & 5 & \\
\hline MS & 73 & $\begin{array}{l}\text { Disciform and lipid } \\
\text { keratopathy }\end{array}$ & Yes & $\begin{array}{l}\text { Penetrating } \\
\mathrm{E} / \mathrm{C} \& 10 \mathrm{~L}\end{array}$ & $6 / 24$ & 4 & \\
\hline GA & 76 & $\begin{array}{l}\text { Neuroparalytic } \\
\text { keratitis }\end{array}$ & - & $\begin{array}{l}\text { Penetrating + } \\
\text { tarsorrhaphgy }\end{array}$ & $6 / 12$ & 4 & $\begin{array}{l}\text { Endothelial } \\
\text { decompensation }\end{array}$ \\
\hline NS & 25 & $\begin{array}{l}\text { Disciform and lipid } \\
\text { keratopathy }\end{array}$ & - & lamella & $6 / 9$ & 2 & \\
\hline
\end{tabular}

$\mathrm{E} / \mathrm{C}=$ Extracapsular cataract extraction

fully justified because safer techniques of intraocular surgery are now available such as extracapsular extraction and viscoelastic substances.

We have to admit that all but one of our successful corneal grafts were in sensitive lipid scarred corneas and those that were vascularised had the vessels successfully closed with argon laser preoperatively. ${ }^{9}$ The only neuroparalytic ulcer grafted was because of perforation. We felt that the main reasons that no such cases were grafted electively was that tarsorrhaphy had achieved a quiet eye, with a stable epithelium and there was a good second eye. If any neuroparalytic or exposure keratitis is to be grafted we would advise an accompanying generous one third temporal tarsorrhaphy.

In our experience properly indicated and properly executed surgery in ophthalmic zoster does not seem to markedly prejudice the surgical outcome or to alter the course of the disease. Although based on small numbers of operative cases we hope that these results will encourage others to undertake surgery more readily in ophthalmic zoster patients. 
We would like to thank Mrs. B. Kendell for secretarial assistance.

\section{References}

${ }^{1}$ Womack LW and Liesegang TJ: Complications of Herpes Zoster Ophthalmicus. Arch Ophthalmol 1983, 101: 42-5.

${ }^{2}$ Marsh RJ and Cooper M: Ophthalmic Zoster mucous plaque keratitis. Br J Ophthalmol 1987, 71: 725-8.

${ }^{3}$ Marsh RJ: Herpes Zoster Keratitis. Trans Ophthalmol Soc UK 1973, 93: 181-90.

${ }^{4}$ Liesegang TJ: Corneal Complications from Herpes
Zoster Ophthalmicus. Ophthalmology 1985, 92: 316-24.

${ }^{5}$ Marsh RJ: Ophthalmic Herpes Zoster. In Darrell RW. Viral diseases of the Eye. Philadelphia: Lea and Febiger 1985, 78-89.

${ }^{6}$ Marsh RJ: Ophthalmic Herpes Zoster. Br J Hosp Med 1976, 609-18.

${ }^{7}$ Edgerton AE: Herpes Zoster Ophthalmicus Report of cases and review of the literature. Arch Ophthalmol 1945, 34: 40-62, 114-53.

${ }^{8}$ Adams GGW, Kirkness CM, Lee JP: Botulinum Toxin A induced protective ptosis. Eye 1987, 1: 603-8.

${ }^{9}$ Marsh RJ and Marshall RJ: The treatment of lipid keratopathy.Br J Ophthalmol 1982, 66: 127-35. 